University of Nebraska - Lincoln

DigitalCommons@University of Nebraska - Lincoln

Nebraska Beef Cattle Reports

Animal Science Department

January 2006

\title{
Effects of Pre- and Postpartum Nutrition on Reproduction in Spring Calving Cows and Calf Feedlot Performance
}

\author{
Leslie Aaron Stalker \\ University of Nebraska-Lincoln, stalkera@byui.edu \\ Don C. Adams \\ University of Nebraska-Lincoln, dadams1@unl.edu \\ Richard N. Funston \\ University of Nebraska-Lincoln, rfunston2@unl.edu \\ Terry J. Klopfenstein \\ University of Nebraska-Lincoln, tklopfenstein1@unl.edu
}

Follow this and additional works at: https://digitalcommons.unl.edu/animalscinbcr

Part of the Animal Sciences Commons

Stalker, Leslie Aaron; Adams, Don C.; Funston, Richard N.; and Klopfenstein, Terry J., "Effects of Pre- and Postpartum Nutrition on Reproduction in Spring Calving Cows and Calf Feedlot Performance" (2006). Nebraska Beef Cattle Reports. 104.

https://digitalcommons.unl.edu/animalscinbcr/104

This Article is brought to you for free and open access by the Animal Science Department at DigitalCommons@University of Nebraska - Lincoln. It has been accepted for inclusion in Nebraska Beef Cattle Reports by an authorized administrator of DigitalCommons@University of Nebraska - Lincoln. 


\section{Effects of Pre- and Postpartum Nutrition on Reproduction in Spring Calving Cows and Calf Feedlot Performance}

\author{
L. Aaron Stalker \\ Don C. Adams \\ Terry J. Klopfenstein \\ Rick N. Funston ${ }^{1}$
}

\section{Summary}

Crossbred, spring calving cows were used in a three-year experiment to evaluate the influence of supplemental protein prepartum and grazing sub-irrigated meadow postpartum on pregnancy rates and calf feedlot performance. Feeding supplement prepartum improved body condition score pre-calving and pre-breeding and increased the percentage of live calves at weaning but did not affect pregnancy rate or steer calf feedlot performance. Grazing sub-irrigated meadow did not change pregnancy rates or feedlot performance.

\section{Introduction}

Beef production systems are comprised of a series of segments with potential for complex interactions. Management changes in one segment may influence the entire system.

Body condition score is a good measure of energy reserves and BCS at calving is among the most important factors affecting pregnancy rate. However, postpartum nutrition also may influence reproduction. Increased nutritional plane both pre- and postpartum has been shown to increase growth rate of calves in many but not all cases. Whether this increased growth rate persists beyond weaning is not known.

Objectives of this study were to determine the effects of pre- and postpartum nutrition and their interaction within an applied production setting on productivity of the entire system, especially cow reproductive performance and calf growth performance through the feedlot.

Table 1. Causes for cows being removed from study.

\begin{tabular}{|c|c|c|c|c|c|c|c|c|c|c|}
\hline \multirow[b]{3}{*}{ Treatment $^{\mathrm{a}}$} & & \multirow[b]{3}{*}{$\mathrm{n}$} & \multicolumn{6}{|c|}{ Injured/died during } & \multirow[b]{3}{*}{ Late $^{\mathrm{b}}$} & \multirow[b]{3}{*}{ Total } \\
\hline & & & \multicolumn{2}{|c|}{ Prepartum } & \multicolumn{2}{|c|}{ Parturition } & \multicolumn{2}{|c|}{ Lactation } & & \\
\hline & & & Cow & Calf & Cow & Calf & Cow & Calf & & \\
\hline Supplement & Meadow & 90 & 0 & 0 & 0 & 0 & 1 & 2 & 1 & 4 \\
\hline Supplement & Hay & 91 & 0 & 0 & 0 & 0 & 0 & 0 & 1 & 1 \\
\hline No Supplement & Meadow & 90 & 2 & 2 & 0 & 2 & 1 & 2 & 1 & 10 \\
\hline No Supplement & Hay & 91 & 0 & 1 & 0 & 2 & 0 & 2 & 4 & 9 \\
\hline
\end{tabular}

asupplement $=$ Cows fed the equivalent of $1 \mathrm{lb} /$ day supplement $(42 \% \mathrm{CP})$ prepartum; No Supplement $=$ Cows not fed supplement prepartum;

Meadow $=$ Cows grazed meadow for 30 days postpartum;

Hay $=$ Cows fed hay for 30 days postpartum.

${ }^{b}$ Cows were removed from the study if calving did not occur by April 20.

\section{Procedure}

In year 1, 136 pregnant, MARC II (four-breed composite:1/4 Angus, 1/4 Gelbvieh, 1/4 Hereford, 1/4 Simmental), spring calving cows age 3 to 5 years were stratified by age and weaning weight of previous calf then assigned randomly to 1) supplement or no supplement prepartum and 2) sub-irrigated meadow or hay postpartum. In year 2 cows were switched to the opposite treatment and switched back to their original treatment in year 3. Cows remained in the experiment unless removed because of injury, reproductive failure, or if calving did not occur by April 20 (Table 1). In year 2 and 3 only 113 cows were used because of reduced forage availability caused by drought.

On December 1, cows were divided into eight pastures of similar size and grazed native upland range at the University of Nebraska, Gudmundsen Sandhills Laboratory, near Whitman, Neb. Either 0 or $1 \mathrm{lb}$ daily of supplement was provided to cows on a pasture basis, three times per week, from December 1 to February 28. On a DM basis, supplement ingredients were: $50.0 \%$ sunflower meal, $47.9 \%$ cottonseed meal, $2.1 \%$ urea; and composition was: $42.0 \% \mathrm{CP}$ and $73.3 \% \mathrm{TDN}$.

Cows were managed in a common group during the calving season (March 1 to April 30) and fed grass hay in a dry lot. Amount of hay fed was adjusted daily in an effort to satisfy appetite but minimize waste and averaged $30.9 \mathrm{lb} /$ cow daily (DM basis). Hay quality was determined by near infrared reflectance spectroscopy at a commercial laboratory (Table 2). Average calving date was March 27. During the period between calving and start of breeding (May 1 to May 31 ), half the cows were fed grass hay and half grazed sub-irrigated meadow. At the beginning of breeding season (June 1) treatment groups were combined and cows grazed upland range as a single group for the remainder of the production cycle. The breeding season lasted 60 days with a 1:20 bull: cow ratio. Diet quality (Table 2) was estimated from masticate samples obtained from esophageally fistulated cows. Weight and body condition score (BCS) of all cows were recorded at beginning (December 1) and end (February 28) of the prepartum supplementation period, at beginning (May 1) and end (May 30) of the postpartum meadow grazing period, and at weaning (first week of October). Cows were examined for pregnancy via rectal palpation by a veterinarian in October.

Calves were weighed within 24 to 48 hours of birth and at weaning. Between 24 and 48 hours of birth, a blood sample was collected from

(Continued on next page) 
each calf in year 2 and 3 . Serum was analyzed for Immunoglobulin G concentration by single radial immunodiffusion. Bull calves were castrated at branding (May).

At weaning, steers (yr $1 \mathrm{n}=61$, yr $2 \mathrm{n}=65$, yr $3 \mathrm{n}=45$ ) received two doses of PRISM 414 days apart and a single dose of One Shot vaccine. Steers were fed for ad libitum intake of grass hay in a dry lot during a two week preconditioning period before being shipped to a feedlot at the West Central Research and Extension Center in North Platte, Neb. (100 mi). Upon arrival steers were fed grass hay at $2.5 \%$ of BW for 7 days. After the 7-day adaptation period, steers were weighed on two consecutive days and implanted with Synovex S and dewormed with Cydectin on the second day. Steers were reimplanted with Revelar S about 100 days prior to slaughter. The starting diet contained $35 \%$ alfalfa and steers were adapted over 14 days to a finishing diet that contained $48 \%$ dry rolled corn, $40 \%$ wet corn gluten feed, $7 \%$ alfalfa and $5 \%$ supplement (DM basis) by replacing alfalfa with corn. Steers were fed in 8 pens corresponding to the prepartum pasture of their dam until it was visually estimated the average 12th rib back fat of all steers was 0.5 in.

Hot carcass weight was obtained at harvest. Dressing percentage was calculated using the unshrunk weight obtained at the feedlot prior to shipment to the abattoir. Following a 24-hour chill, marbling score, fat thickness at the 12th rib, percentage of $\mathrm{KPH}$, longissimus muscle area, yield grade and quality grade were determined.

\section{Results}

Cows fed protein supplement prepartum had greater BCS at the end of the supplementation period $(P<0.001)$, at start of postpartum treatment period $(P<0.001)$ and at start of the breeding season $(P=0.01)$ than cows not fed supplement (Table 3). Feeding supplemental protein did not result in increased pregnancy

Table 2. Upland and sub-irrigated meadow diet and hay quality (mean $\pm S D)$.

\begin{tabular}{lrrr}
\hline Item & \multicolumn{1}{c}{ Year 1 } & \multicolumn{1}{c}{ Year 2 } & \multicolumn{1}{c}{ Year 3 } \\
\hline Upland range diet & & & \\
CP, \% DM & $6.4 \pm 0.6$ & $4.7 \pm 1.4$ & $5.1 \pm 0.1$ \\
TDN, \% DM & $50.8 \pm 5.4$ & $49.0 \pm 0.8$ & $50.6 \pm 0.8$ \\
Hay & $8.6 \pm 1.2$ & $8.7 \pm 0.7$ & $6.3 \pm 0.6$ \\
CP, \% DM & $56.0 \pm 1.8$ & $54.2 \pm 2.1$ & $57.9 \pm 1.3$ \\
TDN, \% DM & & & \\
\hline
\end{tabular}

Table 3. BW, BCS, reproductive performance and milk production of cows fed 0 or $1 \mathrm{lb} /$ day supplement December 1 to February 28 (prepartum) and allowed to graze sub-irrigated meadow or fed grass hay May 1 to May 31 (postpartum).

\begin{tabular}{|c|c|c|c|c|c|c|c|c|}
\hline \multirow[b]{2}{*}{ Item } & \multicolumn{2}{|c|}{ Supplement } & \multicolumn{2}{|c|}{ No Supplement } & \multirow[b]{2}{*}{$\mathrm{SEM}^{\mathrm{a}}$} & \multicolumn{3}{|c|}{ Effect $P$-value ${ }^{\mathrm{b}}$} \\
\hline & Meadow & Hay & Meadow & Hay & & Sup & Mead & SxM \\
\hline \multicolumn{9}{|l|}{ Cow BW, lb } \\
\hline December 1 & 1081 & 1074 & 1088 & 1093 & 29 & 0.16 & 0.95 & 0.52 \\
\hline February 28 & 1078 & 1082 & 1008 & 1048 & 43 & 0.001 & 0.13 & 0.20 \\
\hline May 1 & 986 & 990 & 955 & 987 & 42 & 0.14 & 0.13 & 0.22 \\
\hline May 30 & 1028 & 999 & 1008 & 994 & 55 & 0.24 & 0.06 & 0.52 \\
\hline October 8 & 1071 & 1050 & 1054 & 1061 & 22 & 0.81 & 0.55 & 0.23 \\
\hline \multicolumn{9}{|l|}{ Cow BCS } \\
\hline December 1 & 5.2 & 5.2 & 5.3 & 5.3 & 0.1 & 0.11 & 0.67 & 0.91 \\
\hline February 28 & 5.1 & 5.2 & 4.5 & 4.8 & 0.2 & $<0.001$ & 0.16 & 0.35 \\
\hline May 1 & 4.8 & 4.9 & 4.5 & 4.7 & 0.2 & $<0.001$ & 0.08 & 0.60 \\
\hline May 30 & 5.2 & 4.9 & 5.1 & 4.8 & 0.2 & 0.01 & $<0.001$ & 0.97 \\
\hline October 8 & 5.2 & 5.1 & 5.1 & 5.1 & 0.1 & 0.21 & 0.39 & 0.96 \\
\hline Pregnancy Rate, \% & 94.8 & 91.5 & 89.2 & 91.3 & 5.8 & 0.46 & 0.88 & 0.49 \\
\hline Calves weaned, $\%$ & 95.2 & 99.0 & 90.1 & 89.9 & 3.7 & 0.03 & 0.56 & 0.51 \\
\hline Calving, day of year & 87 & 88 & 84 & 85 & 2 & 0.01 & 0.16 & 0.80 \\
\hline
\end{tabular}

apooled standard error of treatment means, $\mathrm{n}=12$ pastures per treatment.

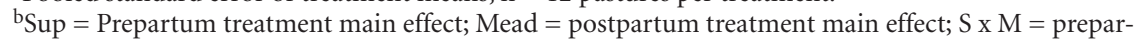
tum $\mathrm{x}$ postpartum treatment interaction.

rates $(P=0.46)$. Similarly, cows that grazed sub-irrigated meadow had greater BCS $(P<0.001)$ at start of breeding but pregnancy rates were not affected $(P=0.88)$. It is likely that pregnancy rates were similar because nonsupplemented and hay fed cows were in acceptable body condition at calving and at start of breeding. Research has shown a BCS of 5 at calving is the critical level affecting subsequent reproduction and cows in all treatments were near a BCS of 5 at calving.

Cows fed supplement calved three days later $(P=0.01)$ than cows not fed supplement but birth weight was similar $(P=0.29)$. Weaning weight and ADG from birth to weaning were greater for calves born to cows fed supplement. Several studies report increased weaning weight of calves born to cows fed supplement prepartum.

The percentage of live calves at weaning was greater $(P=0.03)$ for cows fed supplement prepartum but was not different $(P=0.56)$ between cows that grazed meadow or were fed hay (Table 3 ). Since only pregnant cows were included in the study each year, differences in percentage of live calves at weaning cannot be attributed to failure to conceive. Potentially, failure of passive transfer of immunity could explain differences in weaning rate and weaning weight. In year 2 and 3, IgG titers of calves between 24 and 48 hours after birth were similar $(P=0.98$; Table 4$)$. These results agree with the finding that BCS at calving, ranging from 4 to 7 , does not influence IgG titers of calves.

Steers born to cows fed supplement prepartum that grazed subirrigated meadow were heavier $(P<0.05)$ upon entry into the feedlot than steers born to cows in the other treatment combinations (Table 5). Feedlot ADG $(P=0.89)$, DMI $(P=0.78)$, feed ef- 
Table 4. Growth performance and serum immunoglobulin G concentration of calves born to cows fed 0 or $1 \mathrm{lb}$ /day supplement December 1 to February 28 (prepartum) and allowed to graze sub-irrigated meadow or fed grass hay May 1 to May 31 (postpartum).

\begin{tabular}{|c|c|c|c|c|c|c|c|c|}
\hline \multirow[b]{2}{*}{ Item } & \multicolumn{2}{|c|}{ Supplement } & \multicolumn{2}{|c|}{ No Supplement } & \multirow[b]{2}{*}{ SEM $^{\mathrm{a}}$} & \multicolumn{3}{|c|}{ Effect $P$-value ${ }^{b}$} \\
\hline & Meadow & Hay & Meadow & Hay & & Sup & Mead & SxM \\
\hline $\mathrm{Ig} \mathrm{G}, \mathrm{mg} / 100 \mathrm{ml}^{\mathrm{c}}$ & 3262 & 3068 & 3224 & 3115 & 600 & 0.98 & 0.47 & 0.84 \\
\hline Calf birth wt, lb & 80 & 81 & 79 & 80 & 2 & 0.29 & 0.20 & 0.95 \\
\hline Calf wean wt, lb & 489 & 469 & 470 & 462 & 15 & 0.02 & 0.01 & 0.27 \\
\hline $\begin{array}{l}\text { ADG to wean, } \\
\text { lb/day }\end{array}$ & 2.14 & 2.06 & 2.02 & 1.99 & 0.03 & 0.002 & 0.04 & 0.32 \\
\hline Steer $205 \mathrm{~d} w \mathrm{w}, \mathrm{lb}^{\mathrm{e}}$ & 531 & 511 & 505 & 506 & 15 & 0.13 & 0.35 & 0.30 \\
\hline
\end{tabular}

aPooled standard error of treatment means, $\mathrm{n}=12$ pastures per treatment.

${ }^{\mathrm{b}} \mathrm{Sup}=$ Prepartum treatment main effect; Mead = postpartum treatment main effect; $\mathrm{S} \times \mathrm{M}=$ prepartum x postpartum treatment interaction.

'Immunoglobulin $\mathrm{G}$ concentration in calves between 24 to $48 \mathrm{~h}$ after birth measured by radial immunodiffusion.

${ }^{\mathrm{d}}$ Average daily gain from birth to weaning.

'Weaning weight of steer calves adjusted to $205 \mathrm{~d}$ of age.

Table 5. Finishing performance and carcass characteristics of steer calves born to cows fed 0 or $1 \mathrm{lb} /$ day supplement December 1 to February 28 (prepartum) and allowed to graze sub-irrigated meadow or fed grass hay May 1 to May 31(postpartum).

\begin{tabular}{|c|c|c|c|c|c|c|c|c|}
\hline \multirow[b]{2}{*}{ Item } & \multicolumn{2}{|c|}{ Supplement } & \multicolumn{2}{|c|}{ No Supplement } & \multirow[b]{2}{*}{ SEM $^{\mathrm{a}}$} & \multicolumn{3}{|c|}{ Effect $P$-value ${ }^{b}$} \\
\hline & Meadow & Hay & Meadow & Hay & & Sup & Mead & SxM \\
\hline \multicolumn{9}{|c|}{ Finishing period (222 days) } \\
\hline Start BW, lb & 488 & 461 & 462 & 461 & 5 & 0.01 & 0.01 & 0.01 \\
\hline $\mathrm{ADG}, \mathrm{lb} /$ day & 3.4 & 3.4 & 3.4 & 3.5 & 0.1 & 0.89 & 0.45 & 0.45 \\
\hline DMI, lb/day & 18.9 & 18.7 & 18.5 & 18.9 & 0.4 & 0.78 & 0.71 & 0.44 \\
\hline Life ADG, lb/day ${ }^{\mathrm{c}}$ & 2.7 & 2.7 & 2.6 & 2.7 & 0.04 & 0.32 & 0.94 & 0.23 \\
\hline \multicolumn{9}{|l|}{ Carcass data } \\
\hline $\mathrm{HCW}, \mathrm{lb}$ & 821 & 805 & 796 & 805 & 10 & 0.23 & 0.67 & 0.23 \\
\hline Dressing, $\%$ & 64.8 & 65.0 & 64.6 & 64.5 & 2.4 & 0.13 & 0.96 & 0.49 \\
\hline Marbling score ${ }^{\mathrm{d}}$ & 482 & 476 & 467 & 467 & 9 & 0.23 & 0.76 & 0.74 \\
\hline LMA, in ${ }^{2 e}$ & 13.7 & 13.6 & 13.4 & 13.5 & 0.2 & 0.27 & 0.76 & 0.48 \\
\hline Choice, \% & 94.2 & 89.5 & 87.7 & 83.0 & 4.2 & 0.16 & 0.29 & 0.99 \\
\hline Yield Grade & 2.95 & 3.03 & 2.91 & 3.02 & 0.11 & 0.81 & 0.44 & 0.91 \\
\hline Fat thickness, in ${ }^{\mathrm{f}}$ & 0.52 & 0.54 & 0.50 & 0.53 & 0.03 & 0.81 & 0.26 & 0.92 \\
\hline
\end{tabular}

aPooled standard error of treatment means, $n=8$ pens per treatment.

${ }^{\mathrm{b}} \mathrm{Sup}=$ Prepartum treatment main effect; Mead = postpartum treatment main effect; $\mathrm{S} \times \mathrm{M}=$ prepartum $\mathrm{x}$ postpartum treatment interaction.

${ }^{c}$ Average daily gain from birth to shrunk live weight at slaughter.

${ }^{\mathrm{d}}$ Marbling score: $400=$ Small $^{00}, 500=$ Modest $^{00}$.

étongissimus muscle area.

fFat thickness measured at the 12 th rib. ficiency $(P=0.39)$ and carcass weight $(P=0.23)$ were similar for steers born to supplemented and non-supplemented cows. Likewise, feedlot ADG $(P=0.45)$, DMI $(P=0.71)$, feed efficiency $(P=0.71)$ and carcass weight $(P=0.67)$ were similar for steers born to cows that grazed meadow and cows fed hay. Carcass characteristics were not influenced by either prepartum or postpartum treatment.

\section{Implications}

Results of this study indicate feeding supplement to spring calving cows grazing dormant forage may have benefits beyond impacting reproduction. Feeding supplement to spring calving cows did not improve pregnancy rates but increased percentage of live calves at weaning. These data demonstrate that changes in management have ramifications beyond the segment in which they occur and may influence the entire production system. In this study, prepartum nutrition had a greater affect on subsequent productivity than did postpartum nutrition.

\footnotetext{
${ }^{1}$ Aaron Stalker, graduate student; Don Adams, professor, Animal Science;Rick Funston, associate professor, Animal Science, West Central Research and Extension Center, North Platte; Terry Klopfenstein, professor, Animal Science, Lincoln.
} 